\title{
Rhyme in 16th-Century Hungarian Historical Songs: A Pilot Study
}

\author{
Szilvia Maróthy \\ RCH Institute for Literary Studies, Hungary \\ mthy.szilvi@gmail.com \\ (1) 0000-0003-2558-9504
}

\author{
Levente Seláf
}

ELTE University, Hungary

levente.selaf@gmail.com

(D) 0000-0002-6052-9841

\author{
Petr Plecháč \\ ICL, Czech Academy of Sciences, Czechia \\ plechac@ucl.cas.cz \\ (1) 0000-0002-1003-4541
}

\begin{abstract}
This article presents a computer-based stichometric analysis of 26 Hungarian historical songs from the 16th century. We explore the validity of comments made by Albert Szenci Molnár in 1607 about the poor quality and simplicity of stanza structures in the poetry of previous generations. The study shows how rhyming changed in this poetic genre between 1539 and 1598. In this respect, it is the first work to explore these changes through a quantitative analysis. We find that during the examined period, there was a marked decline in the frequency of rhymes based on the repetition of the same word. At the same time, the tendency to maintain a rhyme across multiple stanzas did not change significantly.
\end{abstract}

\section{Introduction}

In the summer of 2020, our team began a three-year research project dedicated to the computer-based analysis of Hungarian poetry of the 16th century. ${ }^{1}$ The main purpose of this investigation is to provide a preliminary stylometric and stichometric analysis of this corpus.

The project focuses on the oral and written patterns in literature, a matter that has raised much debate. While most poems of the period are closely related to written culture (or their acrostics and colophons at least suggest this link), they have equally strong rhetorical and stylistic components that connect them to oral performance. In addition,they were treated as a type of

1 The members of our team are senior researchers Margit Kiss, Szilvia Maróthy, Petr Plecháč, Levente Seláf, and Artjoms Šela and students Mária Finta, Villő Vigyikán, and Zoé Zohó-Tóth. The authors warmly thank all the participants for their contributions to this article. 
communal poetry by traditional scholarship and early theoretical reflections (see Sir Philip Sidney's comments in his Defence of Poesie, also cited in Seláf (2020)). Our research considers both the inherent oral stylistic patterns and their imitations in this literature. We believe that a stylistic and digital metrical analysis may reveal the structure of multilayered editions,including the textual interventions and modifications of various authors and editors (see Vadai (2009) and Schelhammer (2019) on traces of the different redactions of poems in the given corpus). In this paper, we focus exclusively on a stichometric analysis.

One of the main goals of stylometry and computerized metrical analysis is authorial attribution. In the case of our corpus, however, instead of problems related to doubtful attribution, our concern is with whether the stylistic and metrical features and practices of an author, editor, publisher, or genre are homogeneous. In addition, by examining the unity of texts in the same genre or that were edited or reproduced in the same volumes or by the same persons, our project provides feedback on the validity of the stylometric method regarding authorship in the corpus.

This article is not the first study to employ a data-driven analysis of early modern Hungarian poems. While working on the Repertory of Early Modern Hungarian Verse (RPHA (Horváth et al. 1979-2020)) in the 1980s and early 1990s, Iván Horváth offered a statistical examination and summary of the core characteristics of early modern Hungarian verse based on the so-called iso rule (Horváth 1991). This arose from the observation that the first verse and the first stanza formally determine all subsequent verses and stanzas. This primarily metrical examination helped researchers understand the homogeneity of the corpus, a certain formal simplicity and uniformity that remained characteristic in Hungarian poetry up until the 19th century. Related studies have analyzed groups of poems that significantly differ from the rest of the corpus from different perspectives. This includes, for instance, poems that start with "ab" rhymes (Horváth 1991; Szigeti 2005), those in couplets (Bognár 2016), and those affected by the " +1 rule" concerning metrical boundaries and regularities in oral and written poetry (Vadai 1991, 2012). Theories have been proposed about characteristic features that counterbalance formal homogeneity, for example, by phonetic means (Horváth 1991, 2006) or by constructing complicated acrostics and anaphoric structures that compensate for monotonous rhyme schemes and syllabic structures (Seláf 2017). Hapaxes and poems that diverge from the homogeneous sample have also undergone thorough examination; their technical uniqueness has partially been explained by foreign, mostly Latin and German, influences (Bognár 2016).

\section{The Historical Song in 16th-Century Poetry}

The project consists of two major phases, each of which uses an important subcorpus of poetry of the period. The first phase of research examines the most characteristic genre of Hungarian literature: the historical (narrative or epic) song. Our inquiry focuses mostly on historical songs of the 16th century, but some 17th-century compositions of the same genre that have not previously 
sparked much academic interest are also analyzed. The second phase of the project will examine secular lyric poems of the second half of the 16th century. The present study of rhyme patterns in a select sample of history songs marks our first effort to explore this domain.

The historical song is a traditional genre thought to have emerged in the 15th century or earlier. ${ }^{2}$ While it cannot be confirmed for certain, it appears likely that the the earliest and most important themes of these songs were the past acts of Hungarians. The first known major poet whose literary output focused on ancient and more recent Hungarian history was Sebestyén Tinódi, who was active in the 1540s and 1550s. In 1554, an entire songbook of Tinódi's work entitled Cronica was published under his supervision. The popularity of Tinódi's book and his melodies suggests that his work was an enduring stylistic model for historical songs in Hungary. Although the stanzaic forms used by Tinódi were not of his own invention, his epic songs on historical subjects became the stylistic, musical, and metrical models for later narrative poems on a wide range of themes. These extended from love stories to biblical plots. While more broadly speaking, the historical song genre can be divided into different subgenres based on the themes explored in the songs. From a formal point of view, they are all very similar. Although several genres in the Hungarian poetic tradition reflected trends in European poetry of the Renaissance, especially the Protestant Reformation (e.g. psalm paraphrases), the history song remained popular over an extended period. We can, thus, trace a trajectory from its first surviving specimens in the late 15th century to its gradual disappearance during the 17th century.

\section{Historical Criticism of Early Hungarian Versification}

In the foreword to his book of psalm paraphrases published in 1607, Albert Szenci Molnár harshly criticized the versification techniques of earlier Hungarian poets. This was the first serious analysis of poetical forms, especially rhyming, in Hungarian literature.

Az régi Magyar énekekben pedig avagy semmi egyenlö terminátioc nem voltac, avagy tiz versis egy másután mind egy igében ment ki, àhonnan az historias énekekben, számtalan az soc Vala vala vala. Kin az idegen nemzetec az kic ezt láttyác, nem gyöznec eleget rayta nevetni. De hálá Istennec, ez egynéhány esztendökben az mi emberinkis ékesb verseket szoktac irni. (http: //magyar-irodalom.elte.hu/gepesk/eloszo/12/12.html)

In old Hungarian songs, there were either no rhyming line endings or ten consecutive stanzas/verses ended with the same rhyme. That's why we have countless "vala, vala, vala" [as the rhyme word] in historical songs. Foreign nations who see this cannot stop laughing about it. But thank God, in recent years, some of our people have been writing more ornate stanzas.

2 Szabács viadala, the earliest Hungarian text devoted to a historical event, dates from the last quarter of the 15th century, and its versification bears traces of German literary influence. We assume that there were other historical songs in this period, but we have no information about them. 
Szenci Molnár's criticisms have been cited by many recent scholars, who propose diverse interpretations. Some suggest that Szenci Molnár essentially condemned the use of identical rhyme endings in several consecutive (monorhymed) stanzas (Ötvös et al. 2004). While this may be true, it is worth noting that he also criticised the over-use of rhymes based on repetition of the same word, particularly "vala" ("has been'). This pattern was typical of the history songs of Tinódi and his imitators, works which Szenci Molnár believed to lack artistic merit.

In the analysis that follows, we assess the validity of Szenci Molnár's critique and examine the formal and stylistic characteristics of Hungarian epic verse in general.

\section{Data and Annotation}

For this first phase of this project, we selected 26 poems that dated from the period between 1539 and 1598. In most cases, these works could be dated precisely based on their colophon stanzas. ${ }^{3}$ Nineteen of these poems are attributed to specific authors (11 different persons in total), while seven poems are anonymous. The two most represented authors in our corpus were Sebestyén Tinódi, who was active in the first part of the period (with three poems dating from between 1550 and 1553), and István Bogáti Fazakas, who worked toward the end of the period (with seven poems dating from between 1576 and 1598). They are both major figures in the genre, and in a later phase of the project, we intend to expand the corpus to include the rest of Tinódi's history songs. The texts used for our analysis were mostly taken from the digital anthology Early Modern Hungarian Literature (Jankovics et al. 2000) and partly from the critical edition of Bogáti's works (Ács et al. 2018). The shortest text was a fragment from Szilágyi és Hagymási históriája of 24 stanzas (the lost entire work has an estimated length of 50 stanzas), while the longest one was Eurialus és Lucretia históriája (504 stanzas).

Except for one work by Bogáti, each poem in the corpus was isostrophic, and each stanza was isorhymed and isosyllabic. ${ }^{4}$ Six of the poems were written in tercets and 20 in quatrains. The different meters used ranged from 10-syllable to 19-syllable lines, with the most frequent structures being monorhymed quatrains of 12-syllable or 11-syllable lines, with eight occurrences of each type. One poem by Bogáti contained a first part with 11-syllable lines and a second part with 12-syllable lines. Overall the limited variety of the corpus reflected the formal homogeneity of 16th-century Hungarian poetry rather well.

The poems in raw TXT were tokenized, lemmatized, and morphologically analyzed by means of the emtsv system (Indig et al. (2019) also known as

\footnotetext{
3 See the list of selected poems and associated key data on GitHub, listofpoems.csv. The following three works were not precisely datable although they certainly belong to the same period: 1) Toldi Miklós históriája; 2) História egy Argirus nevü...;and 3) Szép históriás ének az Telamon királyról. Since, however, we wished to trace trends in changing rhyming schemes, these three undatable poems were not included in the figures.

4 This meant that (1) all stanzas had the same syllabic and rhyme structure, (2) every line in a stanza rhymed with the others,and (3)all lines in a stanza were of the same length.
} 
E-magyar; Váradi et al. (2018)). In addition, they were phonetically transcribed using the eSpeak synthesizer. Rhyme recognition was provided by a simple rule-based algorithm, which on inspection turned out to be reliable enough for our needs. Given that a mere match of line-final vowels and/or line-final suffixes was thought sufficient to establish a rhyme in this period, we considered two lines to rhyme with each other if (1) they came from the same stanza and (2) their final vowels and/or their final morphemes were identical. ${ }^{5}$ The output was stored in JSON format. Initially, we encountered serious difficulties when analyzing the morphology of rhyming words because the emstv analyzer was incapable of correctly interpreting some old morphological models with the default vocabulary file. For this reason, we used the special vocabulary for Old and Middle Hungarian developed by Attila Novák and Bálint Sass (Novák 2014; Novák et al. 2016). Based on a manual check of a random sample of 300 line-ending words, we estimated accuracy for our data at approx. 0.9.

\section{Results}

\subsection{Rhymes Between Stanzas and Identical Rhymes}

Szenci Molnár's critique of the proliferation of same-rhymed endings has been understood by most scholars as a comment on the over-use of same-rhymed endings in consecutive stanzas; this was, for example, the interpretation of Ötvös et al. (2004) while Iván Horváth (2009) held that the monorhymed structure had been the target of Szenci Molnár's criticism. To test these claims, we measured the average sequence length in each poem where a sequence was defined as a group of successive stanzas that shared the same final vowel in most of their lines. These values were compared to a theoretical model constructed by randomizing the order of stanzas in each poem 10,000 times. As Figure 1 shows, the differences between the expected and observed values were not statistically significant for most of the poems $(\alpha=0.05)$. We were therefore unable to confirm any overall tendency to group stanzas based on their line endings. These differences in value seemed to decrease over time. However, given the lack of statistical significance, this observation has rather limited relevance.

On examining the observed values on their own, we noted a number of upper outliers in both the first and second half of the period. These included two poems by Tinódi where the rhyme spanned more than 2.5 stanzas on average (Zsigmond császárnak históriája, 1552, RPHA 1495 (2.70) and Egri históriának summája, 1553, RPHA 1292 (2.59)) and another three poems by other authors where it continued over more than 2 stanzas (Ráskai Gáspár: Egy szép história az vitéz Franciskórúl, 1552, RPHA 0322 (2.07); Bogáti: Ez világi nagysok zürzavarról, 1586, RPHA 1158 (2.05); Bogáti: Aspasia asszony, 1587, RPHA 0693 (2.03)). In fact, these results suggest that at least with respect to historical songs, there was no material change in this versification technique in the period preceding Szenci

5 The following vowels were treated as equivalent: $[\mathrm{e}]=[\varepsilon]$ and $[\mathrm{a}]=[\mathrm{p}]$. Vowel length was not taken into account. 


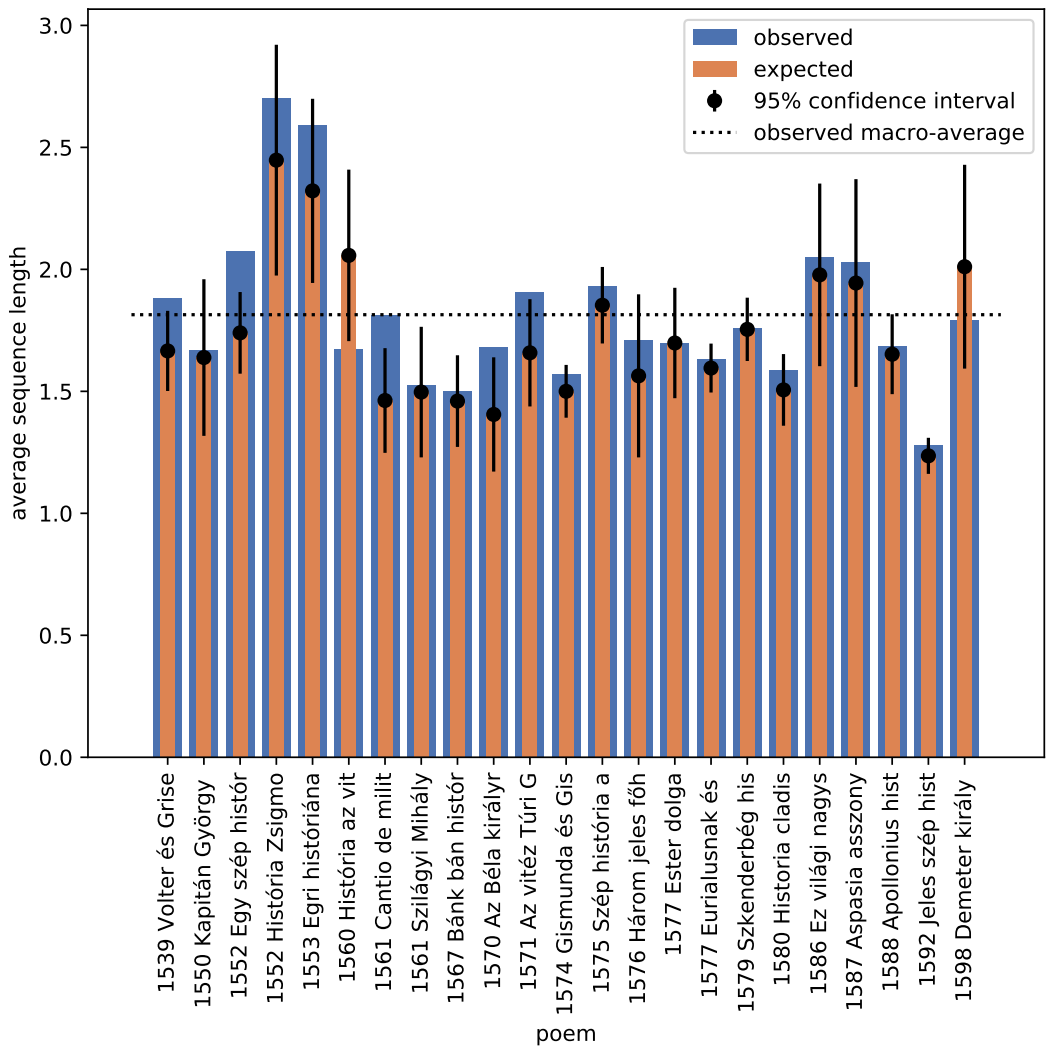

Figure 1: Average observed length of stanza sequences with the same rhyme endings compared with expected length based on a random distribution of all stanzas

Molnár's comment; our analysis of the sample simply did not support such a trend. We must therefore infer that if this change occurred, either it applied to other genres or it related, as Horváth believed, to the technique of building monorhymed stanzas and not the mere use of same rhyme-endings in successive strophes. ${ }^{6}$

However, Szenci Molnár's remark also applied to situations where the rhyme was achieved through the repetition of the very same word. We refer to this phenomenon in this paper as an identical rhyme, and it describes a case where the meaning, spelling, and phonetic form were all the same, e.g.:

Nagy had vala régen Görögországban,

Két szomszéd tartomány öszvevívásban,

Phocis és Thessalia nevek vala,

Ez két had immár szembeszállott vala.

(Bogáti: Szép história az tökéletes asszonyállatokról, v. 21-24.)

${ }^{6}$ In our corpus of historical songs, the non-monorhymed Balassi-strophe (6aa7b6cc7b6dd7b) was limited to a single sample from the 16th century. This was Márton Gyulai’s Epicinia (RPHA-1029). 
Sőt az veszedelmet ha ők értenék,

Az asszonynépeket mind ott égetnék,

Ez tanács az egész hadnak mind tetszék,

Egy ember lőn, kinek jobb tanács tetszék.

(Bogáti: Szép história az tökéletes asszonyállatokról, v. 37-40.)

Significantly, Szenci Molnár singled out the rhyme word "vala” as typical of these poorly rhymed poems. From our analysis, it also appeared that the repetition of this word was extremely popular in rhymes in this period. A total of 1167 of the 1696 identical rhymes, i.e. almost 69\%, consisted of repetition of "vala") and it seems likely that the authors understood this as a distinct style pattern. Figure 2a shows the proportion of identical rhymes involving "vala"-"vala" rhymes among all the rhymes found in particular poems, while Figure $2 \mathrm{~b}$ shows the proportion of lines ending with "vala".

In fact, "vala" may be understood as a special case of suffix rhyme (see Section 5.2). The verb form "vala" is the third-person singular form of the verb "to be" in the past perfect tense, but it also functions as a suffix to express the past perfect or the past imperfect tense of other verbs. In that case, it is written separately and follows the conjugated verb (Verb + PERF.3SG be-PAST or IMPERF.3SG be-PAST). Critics have condemned historical songs for their overreliance on "vala", a tendency that likely results from the genre's general focus on past events and the easy solution these verb forms offer for rhyme.

Figure 2 shows that the use of "vala" rhymes is a salient feature of Tinódi's poems, however it is even more marked in some other poems. It is, for instance, the only identical rhyme appearing in the anonymously authored Szilágyi és Hagymási históriája, which has the highest proportion of identical rhymes (41\%) of any work in the corpus. ${ }^{7}$

The trend over time is clear: there is an ongoing decrease in the use of identical rhymes, and this decline can also be approximated fairly well as a linear function ( $r^{2}=0.41$; Figure 3 ). The pattern becomes even more striking when we compare the two most represented authors in the corpus: Tinódi, who wrote earlier in the period and employed these rhymes considerably, and Bogáti, who was active at the end of the century and used some identical rhymes in his earliest historical song Szép história az tökéletes asszonyállatokról, 1575) but hardly any in his later compositions.

Notably Bogáti not only reduced the percentage of identical rhymes in his poems, but apparently avoided the "vala" rhyme as much as possible, and even extended this stance to the very similar "volna", which is part of the conditional verb form [Cond.NDef.3Sg]. There are no "vala” rhymes whatsoever in E világi nagy sok zürzavarról való ének and only two occurrences of "vala” in a lineending position in Aspasia asszony (the latter has the lowest proportion (0.5\%) of identical rhymes in the corpus). However those two instances occur in stanzas that are distant from each other and are, thus, not considered to rhyme with one another. We may conclude that Bogáti made conscious and increasing efforts to eradicate this kind of rhyme from his poetry.

7 It should be kept in mind, however, that this work is a textual fragment. Only roughly half of the original poem has been preserved. 


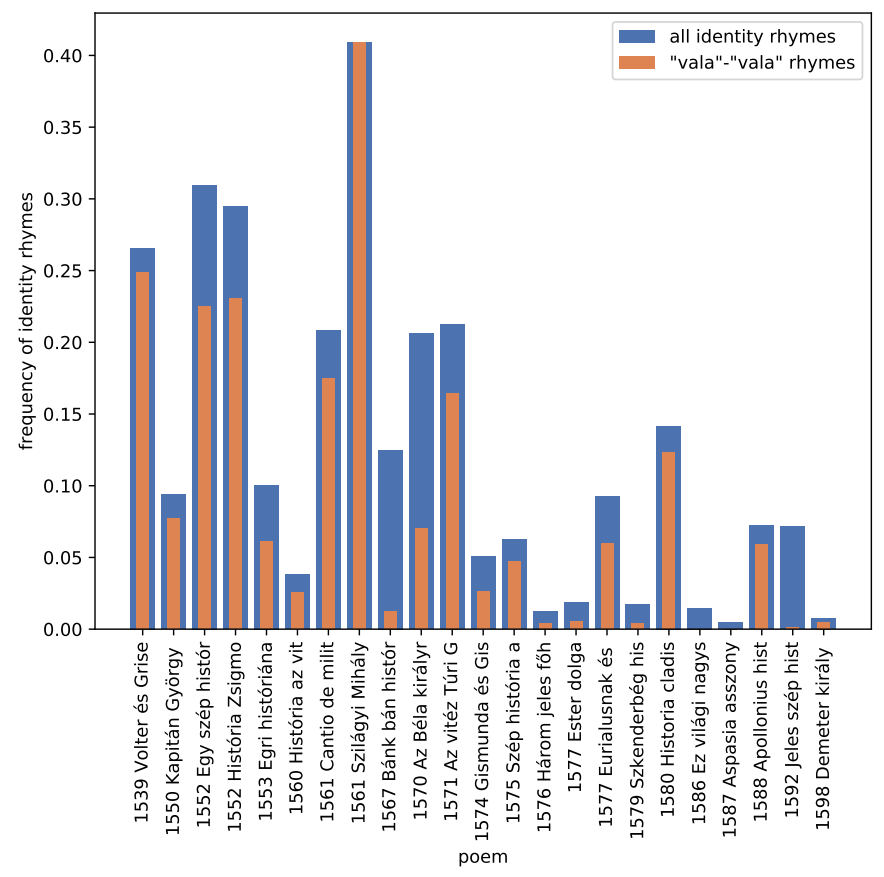

(a) Identical rhymes

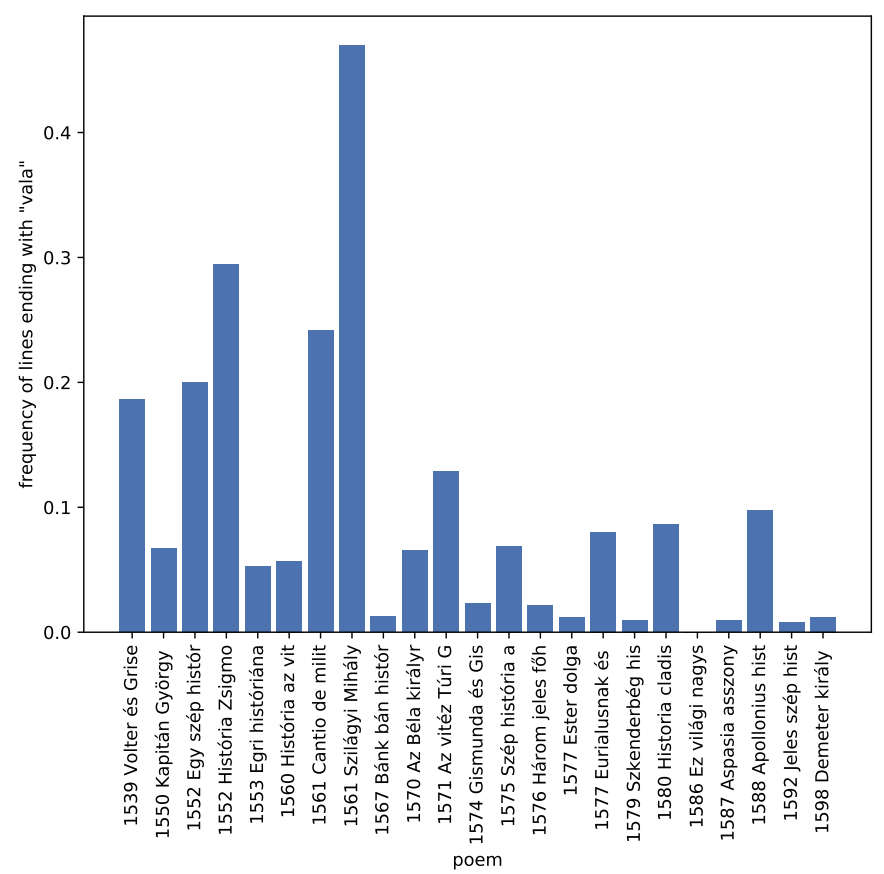

(b) Lines ending with "vala"

Figure 2: Identical rhymes and "vala” rhymes 


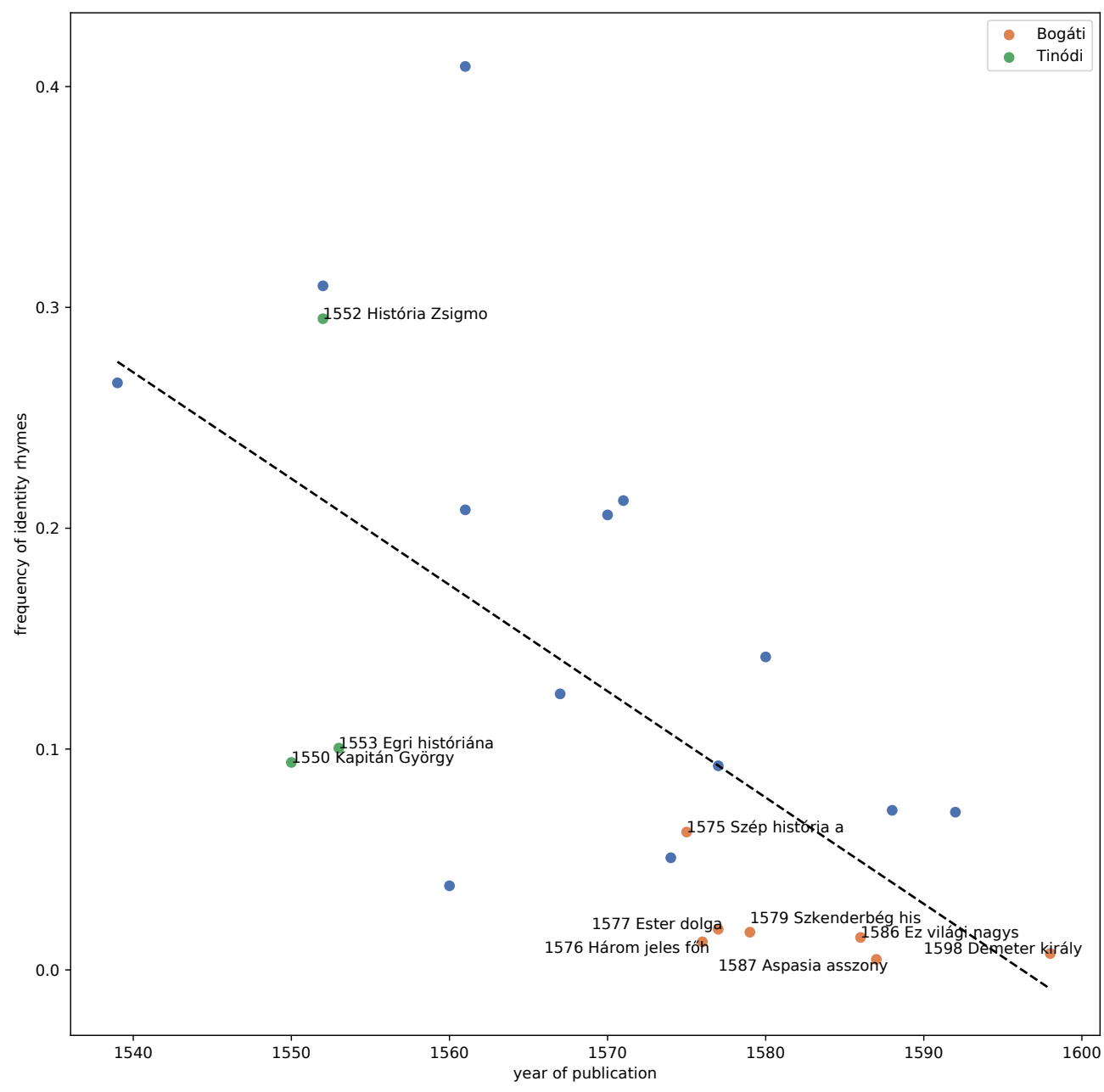

Figure 3: Identical rhymes; linear regression $\left(r^{2}=0.41\right)$

\subsection{Suffix Rhymes}

We understand a suffix rhyme to refer to a pair of rhyming words that each end with the same grammatical suffix. ${ }^{8}$ Figure 4 shows the frequency of these rhymes across all the rhymes in the corpus excluding identical rhymes. As the Hungarian language is agglutinative, rhyming with an identical suffix is rather simple. As such, we hypothesized that sophisticated poets would have attempted to avoid this extremely basic method. Three poems had a very high percentage of suffix rhymes: András Valkai’s Bánk bán históriája (0.65), György Szepesi's Historia cladis Turcicae (0.59), and Tinódi's Kapitány György bajviadala (0.56). Further assessment of the other characteristics of these poems is

8 Some authors use the term grammatical rhyme to describe this situation. 


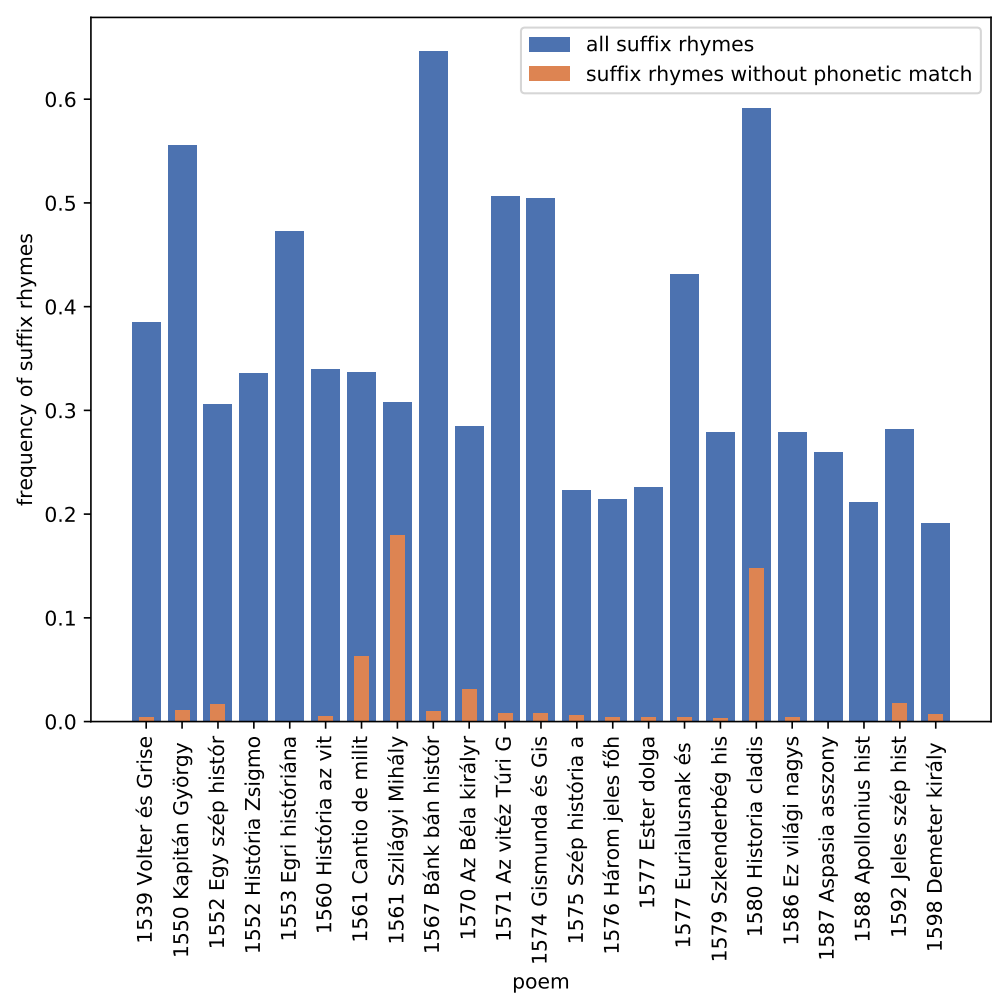

Figure 4: Suffix rhymes

needed, however, to judge whether they showed other weaknesses or managed to compensate for this simplicity.

There is another striking peculiarity of 16th-century Hungarian rhyme that is absent from later poems: some rhyming words have the same grammatical suffix although they differ phonetically. This is true, for example, of -ról/-ről, -ban/-ben, -nak/-nek. The suffixes are phonetically multiform, and the form that corresponds with the phonetic structure of the root is selected. As rhyming by definition requires that (at least) the last vowel in each of two lines be identical, these lines do not rhyme unless we accept that for these authors, the identical grammatical function of the last syllables was an acceptable and sufficient criterion for rhyming. Our data show that two poems in the corpus had a surprisingly high number of unmatching suffix rhymes:the anonymously authored Szilágyi és Hagymási históriája (0.18) and György Szepesi’s Historia cladis Turcicae (0.15), which also had the second highest proportion of suffix rhymes of any kind (i.e. including those that matched). We believe that this is an archaic feature of the versification of these poems and relates to their oral character. Significantly these poems differed from the majority of the corpus since they contained no acrostics and had a weaker relationship with writing 
and written culture. ${ }^{9}$ As mentioned above, Szilágyi és Hagymási históriája also has the highest number of identical rhymes, all of which ended with "vala".

\subsection{Unrhymed Lines}

We also examined the proportion of unrhymed lines in the corpus poems. Unrhymed lines were defined here as lines with a different last vowel than any other line in the same stanza. Again two poems showed significant reliance on the feature: Cantio de militibus pulchra (15.5\%) and Szilágyi és Hagymási históriája (23\%). Both these works were written in $1561 .{ }^{10}$ Cantio has long been connected with oral poetry (Horváth 1984, p. 125), and with a somewhat naive, unschooled poetic tradition. It also contains no acrostics.

Again there was one poem by Bogáti which entirely avoided the feature: (Három jeles föhadnagyoknak vetélkedése) had no unrhymed lines, and Bogáti's other poems all contained only a very limited number of these lines.

\subsection{Consonants and Vowels}

Finally, we compared the last two consonant clusters in rhyming lines and the penultimate vowels in rhyming words (Figure 5). We expected that as rhyming evolved, the number of matching vowels and consonants would increase. We reasoned that as rhyming became more and more sophisticated, poets not only avoided using the same rhyming words in the same stanza but also tried to find words that rhymed better phonetically. However, the only trend that we could detect was a decrease in matching penultimate consonant clusters. Tinódi's long poem dedicated to the siege of Eger had by far the most matches (0.33). In contrast, in Bogáti's poetry, the correspondence was very weak (0.04 to 0.1$)$.

We can only formulate a preliminary hypothesis as to why these rhymes did not become more sophisticated or "richer" over time and why the final and penultimate consonants and the penultimate vowels tended to remain identical. With seven poems in the corpus, Bogáti dominated one end of the time line, and this may be one reason for this curious finding. It may be that because of his various efforts to use complicated acrostics and reduce his reliance on identical rhymes and suffix rhymes, he sometimes needed to settle for rhymes that were weak, with only their last vowel matching. Further investigation and the expansion of the corpus are necessary to assess whether this was a question of personal style or related to more general changes in Hungarian poetry.

\footnotetext{
9 In this tradition, acrostics were almost exclusively constructed from the first letters of consecutive stanzas. Fifteen of the 26 poems in our corpus contained acrostics, see listofpoems.csv.

${ }^{10}$ The kinship of these two poems has been observed by previous scholars; see Orlovszky (2009).
} 


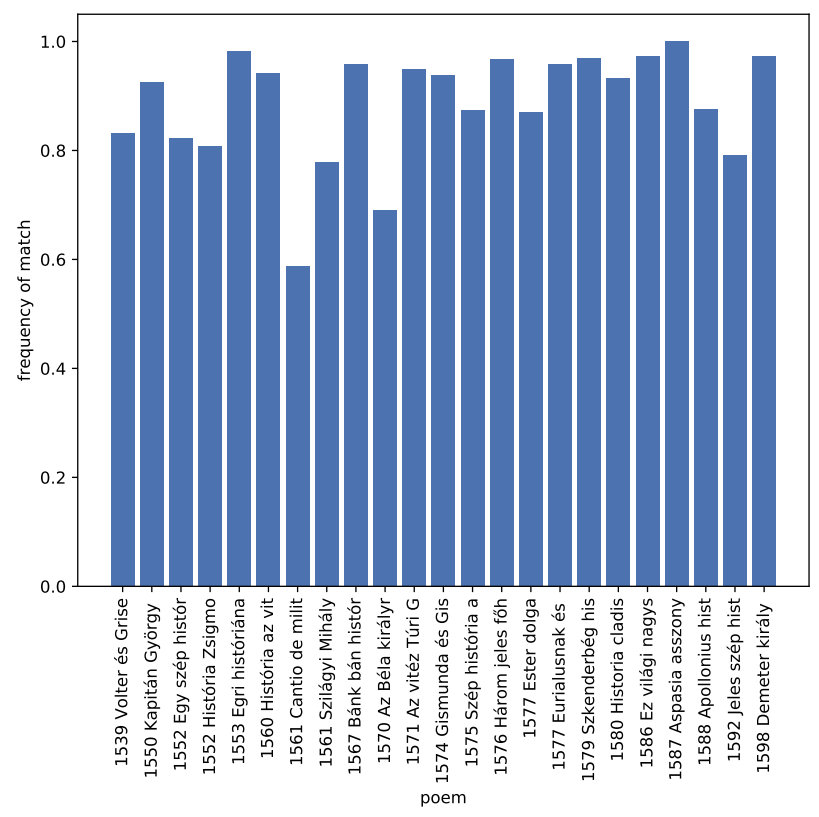

(a) Final consonant cluster

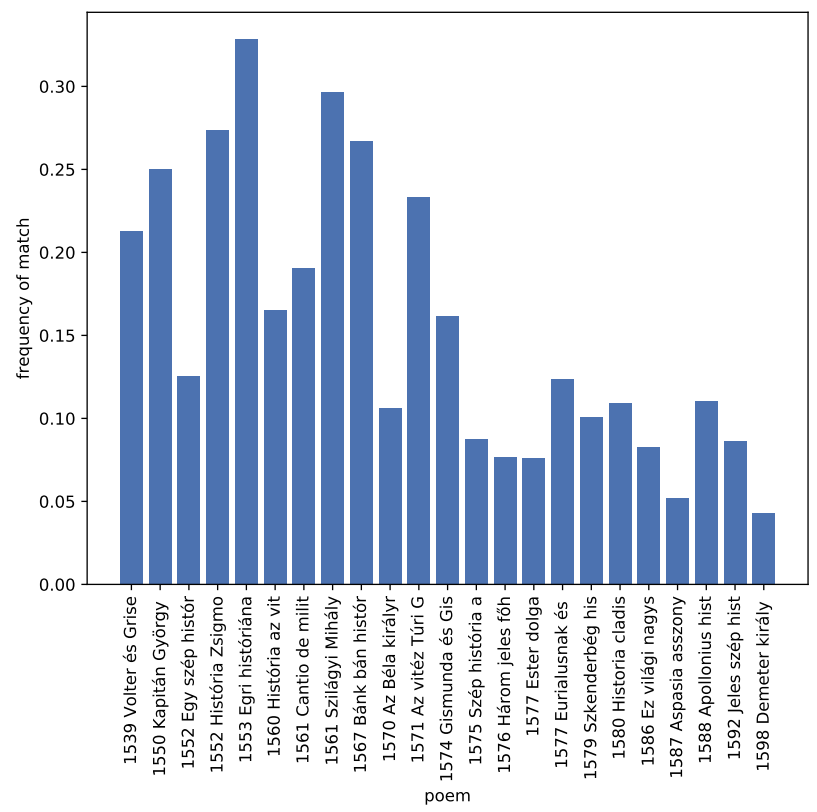

(b) Penultimate consonant cluster

Figure 5: Frequency of matching consonants and vowels. In all cases, identical rhymes and suffix rhymes were excluded from the sample. 


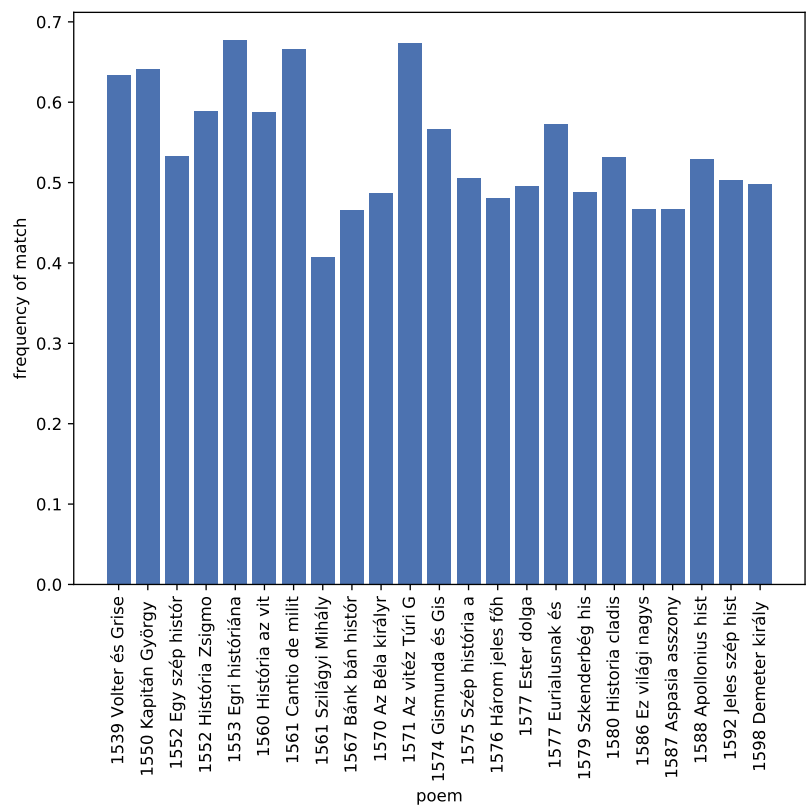

(c) Penultimate vowel

Figure 5: Frequency of matching consonants and vowels (cont.)

\section{Conclusion}

Our analysis revealed a marked change in rhyming techniques in Hungarian historical songs over the examined period. This change took place at different levels and was reflected in an increasing aversion to identical rhymes, unrhyming lines, and phonetically unmatched suffix rhymes. At the same time, based on this corpus alone, we were unable to confirm any change in the use of stanza sequences with the same rhyming syllable by the end of the 16th century. If this shift took place among Szenci Molnár's contemporaries as he professed, then it must have been reflected elsewhere. The expansion of the corpus to include lyric poems may allow us to assess this claim more precisely. It may also reveal distinct and most likely archaic versification patterns in some poems that were less related to literacy than to oral performance and transmission.

As we have noted, the findings of this paper reflect only the first phase of a three-year project. Our research into Hungarian historical songs will proceed on several tracks. We plan to expand the corpus (to 100-150 historical songs) to enable the comparison of subgenres such as songs based on biblical stories and those with more secular content. This expansion will also allow for a better evaluation of personal styles. As a necessity, we will provide a more precise analysis of the grammatical structure of corpus poems. And in the later stages, we will examine the syllabic structure of this verse. Ultimately we hope that this combination of a stylometric analysis and stichometric approach will deliver 
a better understanding of the stylistic patterns of the 16th-century historical songs that we have described.

\section{Acknowledgments}

The research in this study is supported as a National Research, Development and Innovation Office-NKFIH, OTKA 135631 project. Data and code are available at http://github.com/versotym/oldhun.

\section{References}

Ács, Pál, Mihály Etlinger, Balázs Pap, Áron Szatmári, Géza Szentmártoni Szabó, and Edina Zsupán (2018). Bogáti Fazakas Miklós históriás énekei és bibliai parafrázisai. Ed. by Pál Ács, Mihály Etlinger, Balázs Pap, Áron Szatmári, Géza Szentmártoni Szabó, and Edina Zsupán. Régi Magyar Költők Tára, XVI. század 13/A. Budapest: Balassi Kiadó. ISBN: 978-963-456-024-1. URL: http: //real.mtak.hu/80295/ (visited on 11/27/2020).

Bognár, Péter (2016). A régi magyar párrímköltészet német vonatkozásai. Információtörténeti mühely. Budapest: Országos Széchényi Könyvtár.

Horváth, Iván (1984). "Recenzió: Eötvös-füzetek". In: Irodalomtörténeti Közlemények 88.1, pp. 124-126. URL: http://epa.oszk.hu/00000/00001/00334/pdf (visited on 11/30/2020).

Horváth, Iván (1991). A vers: három megközelítés. 2000 Könyvek. Budapest: Gondolat. ISBN: 978-963-7577-00-0.

Horváth, Iván (2006). Gépeskönyv. Budapest: Balassi Kiadó. ISBN: 978-963-506660-5.

Horváth, Iván (2009). “A magyar vers a reneszánsz és reformáció korában. 1536: Megjelenik két verseskötet”. In: A magyar irodalom történetei. Ed. by László Jankovits, Géza Orlovszky, and Iván Horváth. Budapest: Országos Széchényi Könyvtár. URL: https://f-book.com/mi/index.php?chapter=0303HORVAMAG.

Horváth, Iván, Zsuzsa Font, Gabriella H. Hubert, János Herner, Etelka Szőnyi, and István Vadai (1979-2020). Répertoire de la poésie hongroise ancienne, v. 7.0 Beta. URL: https:/f-book.com/rpha/v7/index.php (visited on 11/27/2020).

Indig, Balázs, Bálint Sass, Eszter Simon, Iván Mittelholcz, Noémi Vadász, and Márton Makrai (2019). "One format to rule them all - The emtsv pipeline for Hungarian”. In: Proceedings of the 13th Linguistic Annotation Workshop. Florence, Italy: Association for Computational Linguistics, pp. 155-165. Dor: 10.18653/v1/W19-4018. URL: https://www.aclweb.org/anthology/W19-4018.

Jankovics, József, Péter Kőszeghy, and Géza Szentmártoni Szabó, eds. (2000). Régi magyar irodalmi szöveggyuujjtemény II. Digitális Tankönyvtár. Balassi Kiadó. URL: https://regi.tankonyvtar.hu/hu/tartalom/tkt/regi-magyar-irodalmi-2 (visited on 05/20/2020). 
Novák, Attila (2014). “A New Form of Humor - Mapping Constraint-Based Computational Morphologies to a Finite-State Representation”. In: Proceedings of the Ninth International Conference on Language Resources and Evaluation (LREC'14). Ed. by Nicoletta Calzolari, Khalid Choukri, Thierry Declerck, Hrafn Loftsson, Bente Maegaard, Joseph Mariani, Asuncion Moreno, Jan Odijk, and Stelios Piperidis. Reykjavik, Iceland: European Language Resources Association (ELRA), pp. 26-31. ISBN: 978-2-9517408-8-4.

Novák, Attila, Borbála Siklósi, and Csaba Oravecz (2016). “A New Integrated Open-source Morphological Analyzer for Hungarian”. In: Proceedings of the Tenth International Conference on Language Resources and Evaluation (LREC 2016). Ed. by Nicoletta Calzolari, Khalid Choukri, Thierry Declerck, Sara Goggi, Marko Grobelnik, Bente Maegaard, Joseph Mariani, Helene Mazo, Asuncion Moreno, Jan Odijk, and Stelios Piperidis. event-place: Portorož, Slovenia. Paris, France: European Language Resources Association (ELRA), pp. 23-28. ISBN: 978-2-9517408-9-1.

Orlovszky, Géza (2009). “A históriás ének: 1574: Megjelenik a Cancionale”. In: $A$ magyar irodalom történetei. Ed. by László Jankovits, Géza Orlovszky, and Iván Horváth. Hálózati kiadás. Budapest: Országos Széchényi Könyvtár. URL: https: //irodalom.oszk.hu/villanyspenot/\#!/fejezetek/yJ8pg7P3T4yTMgtHhMYEYA.

Ötvös, Péter, László Szilasi, and István Vadai (2004). "Balassi Bálint: Hymni tres ad Sacrosanctam Trinitatem”. In: Tiszatáj 58.10, pp. 25-43. URL: http: //epa.oszk.hu/00700/00713/00158/pdf (visited on 11/27/2020).

Schelhammer, Zsófia (2019). “Tinódi ismeretlen verseiről”. In: Verso 2.3, pp. 520.

Seláf, Levente (2017). "Poétiques perpendiculaires: les acrostiches versifiés latins dans la poésie hongroise de la Renaissance”. In: The Poetics of Multilingualism - La Poétique du plurilinguisme. Ed. by Patrizia Noel and Levente Seláf. Newcastle upon Tyne, UK: Cambridge Scholars Publishing, pp. 103-120. (Visited on 02/13/2020).

Seláf, Levente (May 2020). "Between Lyric and Epic: The Great Turkish War in German, Italian and Hungarian Ereignisliedern”. In: Controversial Poetry 1400-1625. Ed. by Judith Keßler, Ursula Kundert, and Johan Oosterman. Radboud Studies in Humanities 11. BRILL, pp. 61-86. ISBN: 978-90-04-29191-1. DOI: 10.1163/9789004291911_005. uRL: https://brill.com/view/book/edcoll/ 9789004291911/BP000006.xml (visited on 11/29/2020).

Szigeti, Csaba (2005). Magyar versszak. Budapest: Balassi Kiadó. IsBN: 978-963506-623-0.

Vadai, István (1991). “+1: Metrikai határjelölések a régi magyar versben”. In: Irodalomtörténeti Közlemények 95.4, pp. 351-369. ISSN: 0021-1486. (Visited on 05/28/2019).

Vadai, István (2009). “A tudósító ének műfaja: 1554: Megjelenik Tinódi Sebestyén Cronicája”. In: A magyar irodalom történetei. Ed. by László Jankovits, Géza Orlovszky, and Iván Horváth. Hálózati kiadás. Budapest: Országos Széchényi Könyvtár. URL: https://f-book.com/mi/index.php?chapter=0405VADAATUD.

Vadai, István (2012). “Szóban kettő - írásban négy: az oralitás metrikájáról”. In: Doromb: Közköltészeti tanulmányok 1, pp. 19-41. ISSN: 2063-8175. (Visited on 02/13/2020). 
Váradi, Tamás, Eszter Simon, Bálint Sass, Iván Mittelholcz, Attila Novák, Balázs Indig, Richárd Farkas, and Veronika Vincze (May 2018). "E-magyar - A Digital Language Processing System”. In: Proceedings of the Eleventh International Conference on Language Resources and Evaluation (LREC 2018). Ed. by Nicoletta Calzolari (Conference chair), Khalid Choukri, Christopher Cieri, Thierry Declerck, Sara Goggi, Koiti Hasida, Hitoshi Isahara, Bente Maegaard, Joseph Mariani, Hélène Mazo, Asuncion Moreno, Jan Odijk, Stelios Piperidis, and Takenobu Tokunaga. Miyazaki, Japan: European Language Resources Association (ELRA). ISBN: 979-10-95546-00-9. 